\title{
PERTUMBUHAN DAN HASIL TANAMAN TERUNG UNGU VARIETAS YUMI F1 DENGAN PEMBERIAN BERBAGAI BAHAN ORGANIK DAN LAMA INKUBASI PADA TANAH BERPASIR
}

\author{
TITIN APUNG ATIKAH \\ Dosen Pada Jurusan Budidaya Pertanian Fakultas Pertanian Universitas Palangka Raya
}

\begin{abstract}
The research aims to study the response of plant purple eggplant F1 Yumi variety by providing various organic materials and the proper incubation duration on sandy soil. This research used Completely Randomized Factorial Design. The first factor is giving various organic materials (chicken manure, and kayambang bokashi manure + rice husk charcoal) and the second is the incubation duration (2.4 and 6 weeks before planting).

The results showed that providing various organic materials and the incubation duration highly significant influence on plant height and number of leaves aged 4 and 6 weeks after planted, the number of productive branches and fresh weight of fruit crops, but did not significantly affect the parameters of plant height and number of leaves aged 2 WAP. The highest yield for plant height parameter aged 4 and 6 WAP, number of leaves aged 4 and 6 WAP, number of productive branchs, number of fruits and fresh fruit weight was obtained at bokashi manure + rice husk charcoal treatment with 4 weeks incubation duration before planting.
\end{abstract}

keywords: organic materials, incubation duration, purple eggplant, sandy soil.

\section{ABSTRAK}

Penelitian bertujuan mengetahui respon tanaman terung ungu varietas Yumi $\mathrm{F} 1$ terhadap pemberian berbagai bahan organik maupun lama inkubasi yang tepat pada tanah berpasir. Penelitian ini menggunakan Rancangan Acak Lengkap Faktorial.Faktor Pertama Pemberian berbagai bahan organik (pupuk kandang kotoran ayam, bokashi Kayambang dan bokashi pupuk kandang + arang sekam padi) dan faktor kedua Lama Inkubasi (2, 4 dan 6 minggu sebelum tanam). Hasil penelitian menunjukan pemberian berbagai bahan organik dan lama inkubasi memberikan pengaruh sangat nyata terhadap tinggi tanaman dan jumlah daun umur 4 dan 6 MST, jumlah cabang produktif dan berat segar buah pertanaman, namun tidak berpengaruh nyata terhadap parameter tinggi tanaman dan jumlah daun umur 2 MST. Hasil tertinggi untuk parameter tinggi tanaman umur 4 dan 6 MST, jumlah daun umur 4 dan 6 MST, jumlah cabang produktif, jumlah buah dan berat buah segar diperoleh pada perlakuan pemberian bokashi pupuk kandang + arang sekam padi dengan lama inkubasi 4 minggu sebelum tanam.

\section{Kata Kunci : Bahan organik, lama inkubasi, terung ungu, tanah berpasir}

\section{PENDAHULUAN}

Tanaman terung merupakan salah satu sayuran yang cukup populer dan digemari oleh seluruh lapisan masyarakat. Buah terung yang masih muda selain enak untuk dijadikan berbagai sayuran dan lalapan, juga mengandung gizi yang cukup tinggi dan komposisinya lengkap sehingga komoditas terung sangat potensial untuk dikembangkan secara intensif dalam skala agribisnis sekaligus penyumbang cukup besar terhadap keanekaragaman bahan pangan bergizi bagi penduduk.(Rukmana, 2006)

Berdasarkan data Statistik Hortikultura Kalimantan Tengah tahun 2010, luas areal tanaman terung di Kalimantan Tengah adalah 1.359 /ha dengan produktivitas 29,94 kuintal/ha. Apabila dibandingkan produktivitas terung nasional jumlah ini masih dikategorikan rendah karena secara umum tanaman terung mampu menghasilkan antara 32,64 - 34,11 kuintal/ha. 
Dari data tersebut masih terbuka peluang untuk meningkatkan rata-rata hasil terung melalui penerapan teknologi budidaya.

Kendala utama pembudidayaan terung di Kalimantan Tengah adalah masalah lahan pertanian yang sebagian besar didominasi oleh tanah marginal, salah satunya tanah berpasir yang mempunyai sifat-sifat fisik, kimia dan biologi yang tidak menguntungkan untuk budidaya tanaman dikarenakan miskin unsur hara dan sulit mengikat atau menahan unsur hara dan air (Hardjowigeno, 1992).

Penggunaan bahan-bahan organik merupakan salah satu alternatif dalam upaya meningkatkan kemampuan tanah untuk menahan air dan sekaligus mensuplai unsur hara. Pemberian bahan organik diharapkan dapat meningkatkan kesuburan dan produktivitas tanah karena menurut Lingga dan Marsono (2001) manfaat bahan organik terhadap tanah dan tanaman antara lain : 1) memperbaiki struktur tanah, 2) meningkatkan daya serap tanah terhadap air dan 3) sebagai sumber unsur hara bagi tanaman.

Bahan organik dapat diperoleh dari sisasisa hewan maupun residu tanaman seperti akar, batang dan daun gugur yang dikembalikan ke tanah. Namun demikian pengaruhnya terhadap sifat-sifat tanah besar sekali. Bahan-bahan organik tersebut dapat berupa pupuk organik yang proses perubahannya dapat terjadi secara alami atau buatan misalnya melalui penggunaan pupuk kandang maupun penggunaan jenis bokashi, baik yang berasal dari tumbuhan Kayambang maupun arang sekam padi.

Penggunaan pupuk kandang dapat memperbaiki kesuburan tanah, yaitu dapat menambah unsur hara, meningkatkan humus dan mendorong kehidupan jasad renik sehingga akan dapat memperbaiki sifat fisik dan kimia tanah (Rinsema, 1983 dalam Anton Budiyono, 2011). Ditambahkan Sarief (1989) bahwa pengaruh pemberian pupuk kandang bagi tanah akan menaikan daya menahan air, menambah bahan organik dalam tanah, memperbaiki struktur tanah sehingga merupakan media yang baik bagi pertumbuhan tanaman.

Demikian juga penggunaan tumbuhan Kayambang dan arang sekam padi sebagai bahan bokashi memiliki manfaat penting bagi pertumbuhan tanaman. Bokashi merupakan hasil fermentasi bahan-bahan organik dengan bantuan EM4 (effective mikroorganisme). EM4 adalah suatu kultur campuran berbagai mikroorganisme yang sangat bermanfaat terutama bakteri fotosintesis, bakteri asam laktat, ragi, Actinomycetes dan jamur peragian yang dapat digunakan sebagai inokulan untuk meningkatkan keragaman dan populasi mikroorganisme tanah yang menguntungkan bagi pertumbuhan tanaman (Dipo Yuwono, 2006). Tujuan dari penelitian ini adalah untuk mengetahui respon tanaman Terung Ungu varietas Yumi $\mathrm{F} 1$ terhadap pemberian berbagai bahan organik maupun lama inkubasi pada tanah berpasir.

\section{BAHAN DAN METODE}

\section{Waktu Penelitian.}

Penelitian ini dilaksanakan selama 4 bulan di jalan Cilik Riwut Km. 9 Kecamatan Jekan Raya, Kota Palangka Raya Provinsi Kalimantan Tengah. Analisis tanah dilakukan di laboratorium analitik Universitas Palangka Raya. 


\section{Bahan dan Alat.}

Bahan-bahan yang digunakan adalah benih terung varietas YUMI F1, pupuk kandang kotoran ayam, bokashi kayambang, bokashi pupuk kandang + arang sekam padi (pupuk kandang, arang sekam padi, EM4, gula pasir, dedak dan air), kertas label sampel dan tanah berpasir. Alat-alat yang digunakan adalah kayu bulat, kayu balok papan, cangkul, gergaji, palu, polybag, ember, gayung, meteran, timbangan, plastik putih transparan (UV), Paranet, kamera, alat tulis

\section{Metode Penelitian.}

Penelitian ini menggunakan Rancangan Acak Lengkap (RAL) faktorial dengan dua faktor perlakuan dan 3 ulangan .Faktor I pemberian berbagai bahan organik terdiri dari : $\mathrm{K} 1=$ pupuk kandang kotoran ayam dan $\mathrm{K} 2$ = bokashi kayambang, $\quad \mathrm{K} 3=$ bokashi pupuk kandang + arang sekam padi, sedangkan faktror II lama inkubasi terdiri dari L1=2 minggu sebelum tanam, L2 $=4$ minggu sebelum tanam dan $\mathrm{L} 3=6$ minggu sebelum tanam.

\section{Variabel Pengamatan.}

Variabel yang diamati meliputi : tinggi tanaman (cm), jumlah daun (helai), jumlah cabang produktif, jumlah buah pertanaman (buah) dan berat buah segar pertanaman (gr).

\section{HASIL DAN PEMBAHASAN}

\section{Hasil Pengamatan}

Dari hasil analisis ragam menunjukkan bahwa interaksi pemberian berbagai bahan organik dan lama inkubasi berpengaruh nyata terhadap parameter tinggi tanaman, jumlah daun umur 4 dan 6 MST, jumlah cabang produktif, jumlah buah dan berat buah segar tanaman. Hasil uji beda rata-rata untuk parameter tinggi tanaman, jumlah daun, jumlah cabang produktif, jumlah buah dan berat buah segar tanaman terung disajikan pada Tabel 1, 2, 3, dan 4

Tabel 1. Hasil uji beda rata-rata tinggi tanaman umur 4 MST dan 6 MST

\begin{tabular}{|c|c|c|}
\hline \multirow{2}{*}{ Perlakuan } & \multicolumn{2}{|c|}{ Tinggi Tanaman } \\
\cline { 2 - 3 } & $4 \mathrm{MST}$ & $6 \mathrm{MST}$ \\
\hline $\mathrm{K}_{1} \mathrm{~L}_{1}$ & $8,8 \mathrm{ab}$ & $29,3 \mathrm{bc}$ \\
$\mathrm{K}_{1} \mathrm{~L}_{2}$ & $5,2 \mathrm{a}$ & $20,4 \mathrm{ab}$ \\
$\mathrm{K}_{1} \mathrm{~L}_{3}$ & $4,5 \mathrm{a}$ & $8,9 \mathrm{a}$ \\
$\mathrm{K}_{2} \mathrm{~L}_{1}$ & $8,6 \mathrm{ab}$ & $26,6 \mathrm{bc}$ \\
$\mathrm{K}_{2} \mathrm{~L}_{2}$ & $12,4 \mathrm{bcd}$ & $35,0 \mathrm{bc}$ \\
$\mathrm{K}_{2} \mathrm{~L}_{3}$ & $11,6 \mathrm{bc}$ & $31,1 \mathrm{bc}$ \\
$\mathrm{K}_{3} \mathrm{~L}_{1}$ & $16,3 \mathrm{~cd}$ & $39,7 \mathrm{c}$ \\
$\mathrm{K}_{3} \mathrm{~L}_{2}$ & $18,2 \mathrm{~d}$ & $40,1 \mathrm{c}$ \\
$\mathrm{K}_{3} \mathrm{~L}_{3}$ & $17,1 \mathrm{~cd}$ & $39,1 \mathrm{c}$ \\
\hline BNJ 5\% & 6,10 & 17,36 \\
\hline
\end{tabular}

Keterangan : Angka-angka yang didampingi huruf yang sama pada kolom yang sama tidak berbeda nyatapada uji BNJ taraf $5 \%$ 
Tabel 2. Hasil uji beda rata-rata jumlah daun tanaman umur 4 MST dan 6 MST

\begin{tabular}{|c|c|c|}
\hline \multirow{2}{*}{ Perlakuan } & \multicolumn{2}{|c|}{ Jumlah daun } \\
\cline { 2 - 3 } & $4 \mathrm{MST}$ & $6 \mathrm{MST}$ \\
\cline { 2 - 3 } & $7,7 \mathrm{bc}$ & $17,7 \mathrm{abc}$ \\
$\mathrm{K}_{1} \mathrm{~L}_{1}$ & $6,7 \mathrm{ab}$ & $11,7 \mathrm{ab}$ \\
$\mathrm{K}_{1} \mathrm{~L}_{2}$ & $4,6 \mathrm{a}$ & $7,3 \mathrm{a}$ \\
$\mathrm{K}_{1} \mathrm{~L}_{3}$ & $7,3 \mathrm{abc}$ & $10,3 \mathrm{ab}$ \\
$\mathrm{K}_{2} \mathrm{~L}_{1}$ & $8,7 \mathrm{bc}$ & $20,0 \mathrm{bcd}$ \\
$\mathrm{K}_{2} \mathrm{~L}_{2}$ & $8,0 \mathrm{bc}$ & $16,0 \mathrm{abc}$ \\
$\mathrm{K}_{2} \mathrm{~L}_{3}$ & $9,7 \mathrm{c}$ & $24,7 \mathrm{~cd}$ \\
$\mathrm{~K}_{3} \mathrm{~L}_{1}$ & $10,0 \mathrm{c}$ & $31,3 \mathrm{~d}$ \\
$\mathrm{~K}_{3} \mathrm{~L}_{2}$ & $9,3 \mathrm{bc}$ & $30,3 \mathrm{~cd}$ \\
$\mathrm{~K}_{3} \mathrm{~L}_{3}$ & 2,78 & 11,90 \\
\hline BNJ 5\% & & \\
\hline
\end{tabular}

Keterangan: Angka-angka yang didampingi huruf yang sama pada kolom yang sama tidak berbeda nyata pada uji BNJ taraf $5 \%$

Tabel 3. Hasil uji beda rata-rata Jumlah cabang produktif

\begin{tabular}{|c|c|}
\hline Perlakuan & Jumlah cabang produktif \\
\hline $\mathrm{K}_{1} \mathrm{~L}_{1}$ & $8,3 \mathrm{~cd}$ \\
$\mathrm{~K}_{1} \mathrm{~L}_{2}$ & $4,0 \mathrm{ab}$ \\
$\mathrm{K}_{1} \mathrm{~L}_{3}$ & $2,7 \mathrm{a}$ \\
$\mathrm{K}_{2} \mathrm{~L}_{1}$ & $2,3 \mathrm{a}$ \\
$\mathrm{K}_{2} \mathrm{~L}_{2}$ & $2,3 \mathrm{a}$ \\
$\mathrm{K}_{2} \mathrm{~L}_{3}$ & $2,3 \mathrm{a}$ \\
$\mathrm{K}_{3} \mathrm{~L}_{1}$ & $6,0 \mathrm{bc}$ \\
$\mathrm{K}_{3} \mathrm{~L}_{2}$ & $9,0 \mathrm{~d}$ \\
$\mathrm{~K}_{3} \mathrm{~L}_{3}$ & $8,0 \mathrm{~cd}$ \\
\hline BNJ 5\% & 2,66 \\
\hline
\end{tabular}

Keterangan : Angka-angka yang didampingi huruf yang sama pada kolom yang sama tidak berbeda nyata pada uji BNJ taraf $5 \%$

Tabel 4. Hasil uji beda rata-rata Jumlah buah dan berat buah segar tanaman

\begin{tabular}{|c|c|c|}
\hline Perlakuan & Jumlah buah (buah) & Berat buah segar (gr) \\
\hline $\mathrm{K}_{1} \mathrm{~L}_{1}$ & $3,0 \mathrm{ab}$ & $381,7 \mathrm{~cd}$ \\
$\mathrm{~K}_{1} \mathrm{~L}_{2}$ & $1,7 \mathrm{a}$ & $169,7 \mathrm{ab}$ \\
$\mathrm{K}_{1} \mathrm{~L}_{3}$ & $2,0 \mathrm{a}$ & $177,7 \mathrm{ab}$ \\
$\mathrm{K}_{2} \mathrm{~L}_{1}$ & $2,3 \mathrm{a}$ & $190,3 \mathrm{ab}$ \\
$\mathrm{K}_{2} \mathrm{~L}_{2}$ & $1,0 \mathrm{a}$ & $147,0 \mathrm{a}$ \\
$\mathrm{K}_{2} \mathrm{~L}_{3}$ & $2,3 \mathrm{a}$ & $199,7 \mathrm{ab}$ \\
$\mathrm{K}_{3} \mathrm{~L}_{1}$ & $4,7 \mathrm{~b}$ & $480,3 \mathrm{~d}$ \\
$\mathrm{~K}_{3} \mathrm{~L}_{2}$ & $5,0 \mathrm{~b}$ & $484,3 \mathrm{~d}$ \\
$\mathrm{~K}_{3} \mathrm{~L}_{3}$ & $2,3 \mathrm{a}$ & $308,0 \mathrm{bc}$ \\
\hline BNJ 5\% & 1,26 & 194,38 \\
\hline
\end{tabular}

Keterangan : Angka-angka yang didampingi huruf yang sama pada kolom yang sama tidak berbeda nyata pada uji BNJ taraf $5 \%$ 


\section{Pembahasan}

Pemberian pupuk organik berupa bokashi pupuk kandang + arang sekam padi dengan lama inkubasi 4 minggu sebelum tanam berpengaruh sangat nyata terhadap peningkatan tinggi tanaman dan jumlah daun pada umur 4 dan 6 MST, jumlah cabang produktif, jumlah buah dan berat buah segar tanaman.

Interaksi pemberian bokashi pupuk kandang + arang sekam padi dengan lama inkubasi 4 minggu sebelum tanam $\left(\mathrm{K}_{3} \mathrm{~L}_{2}\right)$ berpengaruh sangat nyata pada parameter tinggi tanaman dan jumlah daun umur 4 dan 6 MST dikarenakan perlakuan ini mampu menyediakan unsur hara makro dan mikro yang dibutuhkan tanaman juga akibat membaiknya sifat fisik, kimia dan biologis tanah sebagai media tanam sehingga meningkatkan kesuburan tanah. Perbaikan sifatsifat tersebut secara langsung dan tidak langsung mempengaruhi status unsur hara yang tersedia dalam tanah sehingga mudah tersedia untuk diabsorbsi yang pada akhirnya mampu mendukung pertumbuhan vegetatif tanaman. Menurut Agustina (2000), tersediannya unsur hara sangat erat hubungannya dengan $\mathrm{pH}$ tanah. Peningkatan $\mathrm{pH}$ tanah kearah netral akan dapat meningkatkan ketersediaan unsur hara seperti $\mathrm{N}$, $\mathrm{P}, \mathrm{K}, \mathrm{S}, \mathrm{Ca}, \mathrm{Mg}$ dan Mo. Humus yang dihasilkan oleh pemberian bokashi pupuk kandang + arang sekam padi mampu memperbaiki struktur tanah, menggemburkan tanah yang kering dan miskin unsur hara.

Secara umum ketersediaan unsur hara dalam tanah berpasir sangat rendah disebabkan tanah berpasir memiliki sifat porositas yang sangat tinggi sehingga menyebabkan unsur hara yang ada mudah hilang dan larut dalam peresapan tanah hal ini menyebabkan tanaman tidak bisa menyerap unsur hara secara sempurna. Interaksi antara beberapa bahan organik dan lama inkubasi tidak berpengaruh nyata terhadap parameter tinggi tanaman maupun jumlah daun pada umur 2 MST hal ini karena pada umur 2 MST tanaman terung baru mulai membentuk perakaran setelah melewati masa adaptasi pemindahan dari tempat persemaian ke dalam polybag sehingga daya serap akar masih belum optimal menyerap unsur hara yang terkandung dalam beberapa bahan organik.

Perlakuan pemberian bokashi pupuk kandang + arang sekam padi dengan lama inkubasi 4 minggu sebelum tanam merupakan perlakuan yang dianggap tepat untuk media tanam terung karena mengandung unsur hara makro dan mikro dalam jumlah yang cukup dalam mendukung pertumbuhan tanaman. Hal ini sesuai dengan pendapat Hardjowigeno (1992) bahwa dengan ketersediaan unsur hara dalam jumlah cukup dapat memacu pertumbuhan dan perkembangan tanaman. Ditambahkan Sarief (1989), bahwa dengan tersediannya unsur hara dalam jumlah cukup memadai maka proses fisiologis di dalam tanaman akan berjalan dengan baik. Hal ini ditunjukkkan dengan semakin meningkatnya pertumbuhan tinggi tanaman, jumlah daun, jumlah cabang produktif, jumlah buah maupun berat buah segar tanaman.

Secara umum kandungan unsur hara yang ada pada bokashi pupuk kandang + arang sekam padi mempunyai peranan penting baik dalam memperbaiki kesuburan tanah maupun dalam proses metabolisme tanaman terung. Bokashi pupuk kandang + arang sekam padi merupakan salah satu jenis bahan yang 
mengandung unsur-unsur yang dibutuhkan tanaman, sehingga dapat dijadikan sebagai sumber bahan organik. Yatazawa dan Suselo (1979) dalam Widiastuti (2006) mengutarakan bahwa bokashi pupuk kandang + arang sekam padi dapat mengikat nitrogen dari udara.

Ditambahkan Widiana dalam suryanto, 2012 bahwa bokashi dapat menyuburkan tanah karena EM-4 mengandung mikroorganisme yang bermanfaat bagi tanah sehingga lapisan olah tanah menjadi lebih dalam dan ruang gerak akar menjadi bertambah luas. Secara kimia EM-4 dapat meningkatkan $\mathrm{pH}$ tanah kearah netral sehingga ketersediaan unsur hara menjadi semakin tinggi bagi perakaran tanaman. Secara biologi EM-4 dapat meningkatkan populasi mikroorganisme fermentasi dan sintetik sehingga pertumbuhan penyakit dan serangga dapat ditekan.

Demikian pula unsur hara makro N, P, K, $\mathrm{Ca}$ dan $\mathrm{Mg}$ serta unsur mikro yang terkandung dalam bokashi pupuk kandang sangat bermanfaat dalam proses metabolisme tanaman. Unsur Nitrogen berperan untuk merangsang pertumbuhan vegetatif tanaman, pembentuk klorofil, protein maupun lemak, disamping itu juga bermanfaat sebagai penyusun enzim dan molekul klorofil yang terdapat didalam sel sehingga mempengaruhi ketersediaan karbohidrat yang sangat berperan dalam pertumbuhan tanaman (Lingga, 2000). Karbohidrat merupakan bahan yang sangat diperlukan dalam pembelahan, pembesaran sel dan pembentuk jaringan untuk perkembangan batang, daun dan akar (Sosrosoedirdjo, 2000).

Unsur hara fosfor yang terkandung dalam bokashi pupuk kandang juga sangat berperan hampir pada seluruh proses kehidupan tanaman. Hardjowigeno (1995) menambahkan bahwa fungsi fosfor bagi tanaman adalah untuk pembelahan sel, memperkuat batang agar tidak mudah roboh serta menambah daya tahan terhadap serangan hama dan penyakit. Fosfor juga berperan dalam transfer energi sebagai bagian dari Adenosin Tri Phosphat (ATP), penyusun protein, Koenzim dan asam nukleat. Kalium berfungsi untuk mengatur berbagai mekanisme metabolik seperti fotosintesa, translokasi karbohidrat dan sintesa protein sehingga meningkatkan ketahanan terhadap penyakit. Megnesium merupakan sistem pembentuk klorofil dan minyak, juga sebagai kofaktor dari berbagai enzim dalam tanaman.

Peningkatan jumlah cabang produktif, jumlah buah serta berat buah segar tanaman pada perlakuan pemberian bokashi pupuk kandang + arang sekam padi dengan lama inkubasi 4 minggu sebelum tanam $\left(\mathrm{K}_{3} \mathrm{~L}_{2}\right)$ erat kaitannya dengan peningkatan tinggi tanaman maupun jumlah daun. Sastrahidayat dan Soemarsono (2002) menyatakan bahwa pertumbuhan tanaman tergantung pada imbangan fotosintesis yang mengimbangi karbohidrat dan bahan tanam serta respirasi, karena fotosintesis pada umumnya terjadi pada daun yang berklorofil maka sampai fase tertentu laju fotosintesis akan meningkat dengan meningkatnya jumlah daun dan luas daun serta pertumbuhan tanaman akan mengikutinya. 


\section{KESIMPULAN DAN SARAN}

\section{Kesimpulan}

Berdasarkan hasil penelitian yang telah dikemukakan disimpulkan bahwa :

a. Interaksi perlakuan pemberian beberapa jenis bahan oganik dan lama inkubasi memberikan pengaruh sangat nyata terhadap parameter tinggi tanaman dan jumlah daun umur 4 dan 6 MST, jumlah cabang produktif, jumlah buah dan berat buah segar tanaman.

b. Hasil tertinggi untuk parameter tinggi tanaman umur 4 dan 6 MST $(18,2 \mathrm{~cm}$ dan $40,1 \mathrm{~cm})$, jumlah daun umur 4 dan 6 MST $(10,0$ helai dan 31,3 helai), jumlah cabang produktif $(9,0$ cabang), jumlah buah (5,0 buah) dan berat buah segar $(484,3 \mathrm{~g})$ diperoleh pada perlakuan interaksi pemberian bokashi pupuk kandang + arang sekam padi dengan lama inkubasi 4 minggu sebelum tanam $\left(\mathrm{K}_{3} \mathrm{~L}_{2}\right)$

Saran

Untuk pembudidayaan tanaman terung ditanah berpasir disarankan untuk mempertimbangkan penggunaan jenis bahan organik bokashi pupuk kandang + arang sekam padi dengan lama inkubasi 4 minggu sebelum tanam karena mampu memberikan hasil tertinggi terhadap parameter pertumbuhan maupun hasil tanaman terung.

\section{DAFTAR PUSTAKA}

Agustina, 2000. Nutrisi Tanaman. Renika Cipta. Jakarta

Anton Budiyono, 2011. Pengaruh Pemberian Bokashi Pupuk Kandang Kotoran Ayam + Arang Sekam Padi dan Pupuk NPK terhadap Pertumbuhan dan Hasil Tanaman Bawang Daun (Allium fistulosum.L) pada Tanah Berpasir.
Skripsi. Program Studi Agroteknologi. Fakultas Pertanian. Universitas Muhammadiyah Palangkaraya

Badan Pusat Statistik Hortikultura Propinsi Kalimantan Tengah.2010. Luas Panen, Produktivitas dan Produksi Sayuran dan Buah-buahan Semusim. Kalimantan Tengah

Dipo Yuwono, 2006. Kompos. Penebar Swadaya. Jakarta

Hardjowigeno, 1992. Ilmu Tanah. PT. Madiatama Sarana Perkasa. Jakarta

Hardjowigeno, 1995. Ilmu Tanah. PT. Mediatama Sarana Perkasa. Jakarta

Lingga.P. 2000. Petunjuk Penggunaan Pupuk. Penebar Swadaya. Jakarta

Lingga.P. dan Marsono, 2001. Petunjuk Penggunaan Pupuk. Penebar Swadaya. Jakarta.

Rukmana. 2006. Bertanam Terung. Penerbit Kanisius. Yogyakarta

Sastrahidayat dan Soemarsono, 2000. Budidaya Tanaman Tropika. Usaha Tani Nasional. Bandung

Sosrosoedirdjo, 2000. IImu Memupuk. CV. Yasaguna. Jakarta

Widiastuti, L. 2006. Pengaruh Penambahan Kayambang (Salvinia molesta) sebagai pupuk organic terhadap Pertumbuhan dan Hasil Bawang Daun semi di Tanah Gambut Pedalaman. Tesis Sekolah Pasca Sarjana Universitas Gadjah Mada. 